\title{
Vymístění uvniłř životního světa: kulturní vymístění jako přepis
}

\author{
Csaba Szaló
}

Pojem vymístění nám může posloužit jako konceptuální nástroj interpretace souvislostí sociálních a kulturních změn. Vymístění lidských bytostí je vždy provázáno s vymístěním symbolických objektů jejich životního světa. O vymístění symbolických objektů můžeme uvažovat ve smyslu vymístění významů těchto objektů. První část textu načrtává diskurzivní proměnu pojmu vymístění. Další část - pojednání o andělech - nastíní vymístění v podobě přeměny žité př́itomnosti symbolických objektů. Třetí část textu objasňuje zmíněnou propletenost/provázanost dvou forem vymístění pomoci interpretačního rámce, jenž pojímá misto ve smyslu existenciálního prostoru lidských bytostí. Čtenářům, kteří neradi čtou způsobem procházky, jež je vedena předem vymezenou cestou, a preferují před svou cestou podrobné prostudování mapy - aby již předem věděli, co je na dané cestě čeká a kam je tato zavede - doporučuji přečíst nejdříve shrnující závěr, jenž najdou na konci textu.

\section{Vymístění jako přepis významů}

Jak hluboce a široce pojmout vymístění? Vymístění není přesunem: je to víc než pouhý přesun objektu v prostoru. Vymístění není holým přesunem lidských bytostí z jednoho místa na jiné, ani holým posunutím významů symbolických objektů z jednoho kulturního pole do jiného. Vymístění dále není ani eliminací. Není odstraněním, vyloučením lidí či vytěsněním významů. Kde však leží hranice mezi vymístěním a přesunem, mezi vymístěním a eliminací? Jestliže vymístění chápeme jako něco, co je víc než pouhý přesun, nedochází pak ke skutečnému vymístění právě při eliminaci? Není náhodou vymístění pouze mírnější podobou eliminace? Neprojevuje se skutečná podstata vymístění právě v eliminaci? Není vymístění jenom jakýmsi pomyslným dodatkem reálné eliminace? Není.

Vymístění lidí není genocidou. Obdobně, vymístění jako přeměna významů není nahrazením starého významu významem novým. Jde spiše o vrstvení významů, než o jejich odstranění či vytěsnění. Jde více o přeškrtnutí, přepsání než o vymazání znaků. ${ }^{1}$ Jde spíše o degradaci než o likvidaci lidí a významů. Mnohdy nemusí starý král zemřít nebo být popraven, aby mohl nastoupit král nový. Může se odebrat (nebo být zahnán) do penze, do vyhnanství, do kláštera. Může dokonce zůstat nominálně králem, avšak králem nebýt, nevládnout. Může se jen tak procházet v zahradě. Podobně, staré významy mohou být vymístěny, aniž by byly eliminovány. Lidské bytosti mohou být vymístěny, aniž by byly vyvražděny. Eventuálně, mohou být vymístěny a zůstat přitom na místě. ${ }^{2}$

Psychoanalýza je formou myšlení a řeči, jež ,jako první“ artikulovala pojem vymístění, a to ve smyslu přeměny významu ve snech (Krupnick 1983: 1-17, Freud 1966: 199-250). ${ }^{3}$

Sociální studia. Fakulta sociálních studií Masarykovy univerzity v Brně, 2/2004. S. 27-41. ISSN 1214-813X. 
Máme však před sebou dva původní významy vymístění (Spivak 1983: 172). Na jedné straně vymístění odkazuje k mechanismu přemístění (Verschiebung) na straně druhé ke komplexnímu procesu distorze (Entstellung). Vymístění můžeme pojímat jako přemístění vztahu cathexis (Besetzung) - mentálního a emocionálního vztahu zaměřenosti, zájmu či připoutanosti - z jednoho symbolického objektu na jiný. Vymístění/přemístění v tomto př́ípadě postupuje prostřednictvím řetězce asociací propojujících původní znak se znakem zastupujícím, na který byly původní zájem, důraz či zaměření přemístěny (Rycroft 1972: 35-36). Mechanismus vymístění/přemístění tím vytváří vztah označování mezi původními a zástupnými znaky. ${ }^{4}$ Zástupný symbolický objekt se tak stane nositelem další vrstvy významu. Obraz otisků v písku může být, kromě toho, že zobrazuje otisky v písku, zástupcem obrazu vlnění moře, jež s pomalou, ale naprostou jistotou odemílá kus břehu. Tento druhý obraz může dál odkazovat k představě neúprosného času, jenž smývá naše vzpomínky. Řetězec asociací, řetězec znaků však není nahodilou konfigurací významů. Vymístění/přemístění je mechanismem nenahodilé podoby vztahu označování. Spojení mezi označovaným a označujícím, propojenost původního a zástupného symbolického objektu nemohou být podle psychoanalýzy vykládány jako výsledek náhody či konvence. Klíčem k této nenahodilosti mechanismu vymístění/přemístění je právě širší pojetí vymístění v podobě procesu distorze.

Pojem vymístění/distorze odkazuje k celkovému procesu snění ve smyslu snové práce. Mechanismus vymístění/přemístění spolu s mechanizmem zhuštění tvoří součást primárního, nevědomého procesu myšlení patrného ve snění. Proces snové práce umožňuje, aby v průběhu snění jisté mentální obrazy zastupovaly či symbolizovaly obrazy jiné. Mechanismus vymístění/přemístění umožňuje, aby symbolický objekt odkazoval na něco jiného, než je on sám, aby reprezentoval něco jiného. Mechanismus zhuštění umožňuje, aby symbolický objekt zastupoval více latentních obsahů najednou, umožňuje, aby byl symbolický objekt reprezentantem více původních významů. Spánek je prostorem, ve kterém se mohou vynořit konfliktní touhy, případně traumatické vzpomínky. Síla vytěsnění, jež nedovoluje těmto touhám či vzpomínkám zjevit se mimo prostor spánku, je ve spánku oslabena. Není však oslabena natolik, aby se tyto vytěsnění-hodné významy z nevědomí vynořily v jejich plné realitě. Snění, přesněji snová práce, je procesem převlečení, maskování, tedy procesem přeměny původního a skrytého významu do přijatelné podoby zjevených symbolů. Vymístění jako Entstellung odkazuje právě k této přeměně významů ve smyslu překroucení či zkomolení. Vymístění/distorze se tak stává dílem cenzury. Původní a skutečný význam textu snu musí přetrpět proces transformace do přijatelné podoby. Cenzura není pouze škrtáním. Není pouze vyloučením určitých významů z konkrétního diskurzu. Cenzura je více než marginalizace určitých významů. Je více než jejich vytěsnění na okraj, mimo pole textu. Ve smyslu vymístění/distorze je cenzura procesem přepsání. Cenzura je přeměna významu, přepis původního textu do nové, přijatelné, avšak zkomolené podoby zjeveného textu.

Důležitým dodatkem procesu vymístění/distorze je tkaní př́iběhu ze symbolických obsahů zjeveného snu. ${ }^{5}$ Jde o proces zřetězení bezesmyslných a nespojitých obrazů, které jsou výsledkem symbolizační práce zhuštění a přemístění. Vymístěné/překroucené, a tím pádem zjevené a přijatelné významy, získávají podle této představy smysl díky dodatku ve formě tvorby srozumitelného příběhu. Vyprávěním získávají významy zjevené prostřednictvím vymístění sociální a kulturní rozměr. Ocitají se v konkrétním/určitém diskurzu. Prostřednictvím verbalizace 
či zápisu se zjevené významy stávají elementy intersubjektivně ovládaného pole řeči a vědění. Začleňováním do př́běhu získávají koherenci a vnitřní konzistenci. Vyprávění je součástí sekundárního procesu myšlení, jenž je ř́zen principem reality a následuje požadavky gramatiky a formální logiky (Rycroft 1972: 148). Ve vztahu k sekundární korekci v podobě vyprávění je vymístění/distorze vlastně ,primární korekci““. Vymístění/distorze bez procesu sekundární korekce však zůstává sociálně nefunkční. Bez vyprávění nemohou zjevené významy vstoupit do intersubjektivního světa kultury a zůstávají skryté v subjektivním světě jednotlivce. Subjektivně zjevené významy nemohou být kulturně reinterpretované a sociálně cenzurované bez jejich proměny ve sdělení ve formě vyprávění. $V$ tomto smyslu odkazuje vymístění/ distorze na dvojí proces: k prvnímu vymístění „,původních významů“ dochází při „,zjevení symbolických objektư “ v subjektivním procesu snění, $\mathrm{k}$ druhému vymístění pak dochází při intersubjektivnim ${ }^{6}$ procesu „,vyprávění o zjevených symbolických objektech“.

Postup psychoanalytické interpretace vlastně proces vymístění/distorze obrací. Sleduje cestu od verbalizovaných a zjevených významů k významům skrytým. Postup interpretace pomocí asociací hledá stezky, které vedou ke skrytým vzpomínkám, představám a touhám. Asociace - díky svým strukturálním podobnostem se skrytými snovými představami - mohou naznačit způsoby dekódování zhuštěných, přemístěných, symbolizovaných a do-příběhů-tkaných původních významů. Tento model interpretace, který použil Freud při výkladu snů, se stal jeho centrálním modelem také pro interpretaci jiných duševních a kulturních jevů. Původní význam se zjevuje pouze v přstrojení. Význam textu, význam viditelného symbolu, spočívá $\mathrm{v}$ tom, že odkazuje $\mathrm{k}$ něčemu jinému. Textualita překrývá dynamiku přeměny, jež je přestrojením skrytého a původního významu. Text je polem interpretace, jež hledá a odkrývá hlubší, to jest skrytý, a proto původní význam.

Z hlediska sociologie je užitečné chápat vymístění ve smyslu, jenž vychází z pojmu vymístění/distorze, nebot' se nám tím odhalují sociální a intersubjektivní dimenze přeměny významů. Vymístění/distorze ve smyslu cenzury je teoretickým původcem psychoanalytického konceptu superega, jenž zastupuje vnější sociální a kulturní sílu. Superego představuje mravní hodnoty a sociální normy. Je místem sebepozorování a sebekritiky. Moc rodičů, jejichž zvnitřněný obraz je jádrem superega, je však reprezentací širší, hlubší či vyšší moci. Vymístění/distorze spolu s verbalizací vymístěných významů v podobě vyprávění jasně směřuje k intersubjektivnímu zakotvení této přeměny významů. Proces přepsání významů je propojen s mocí - vymístění/distorze je projevem formativní moci společnosti a kultury.

Vymístění bychom tedy na základě tohoto psychoanalytického exkurzu měli chápat jako sociálně/kulturně danou transformaci původního významu do nové, zkomolené podoby. Vymístění je přepsáním, re-interpretací. Vymístění jako distorze se však neobejde ani bez dodatku následného vyprávění (inskripce do diskurzu), ani bez elementu vymístění/přemístění (metonymická forma symbolizace). Psychoanalýza je formou myšlení a řeči, jež sama vymístění ve smyslu přeměny významů realizuje. Například subjekt ve smyslu poznávajícího, sebevědomého a tvořícího člověka není z diskurzu psychoanalýzy odstraněný či vyloučený, ale vymístěný. Jeho vymístění spočívá v přeměně jeho významů, jeho pozice či statusu. Subjekt je vymístěn z pozice centra diskurzu o člověku. Vědomí a ego jsou vymístěny z centrální pozice původu a principu existence lidských bytostí (Ricoeur 1974: 241). Klíčovým symptomem vymístění významu je i v tomto př́ípadě přemístění jádra či centra textu, ve kterém se 
význam artikuluje. Elementy, které jsou ve skrytém snovém textu centrální, se ve zjeveném snovém textu objevují jako elementy vedlejší, ne-centrální (Freud: 1966: 218). Podobně je tomu v případě psychoanalytického vymístění subjektu, které se uskutečňuje v podobě reinterpretace partikulární intelektuální tradice: subjekt jako centrální element původního textu se v reinterpretovaném textu objevuje jako vedlejší element.

Idea vymístění jako procesu de-centrace textu se stala klíčovým prvkem též v rámci diskurzu dekonstrukce. Dekonstrukce osvobozuje proces vymístění od jeho zakotvení v představě původního a skrytého významu. Z perspektivy dekonstrukce je vymístění významů pojímáno jako nepředpověditelná a nahodilá přeměna významu (Derrida 1981: 45-57, Derrida 1978a, 1978b). ${ }^{7}$ Je procesem nikdy nekončící re-interpretace. Jádrem či centrem psychoanalytické teorie vymístění je představa pra-textu, tj. textu původních a skrytých významů. Vymístěním této představy původního významu v diskurzu dekonstrukce se stává proces vymístění nezastavitelným a nekontrolovatelným procesem. Nejde přitom o eliminaci ideje původního významu, jde o vymístění ideje původu jako základu. Každý význam se může stát původním významem. Každý text může zaujmout strukturální pozici původního textu. Každý přepsaný text odkazuje k textu původnímu ve smyslu textu-před-přepsáním. Koncept vymístění tím pádem ztrácí jednoznačný „směr“ přeměny vedoucí od původních a skrytých významů k významům zjeveným a cenzurovaným. Tento směr je v diskurzu psychoanalýzy jasně zakotven v osvícenském mýtu historického vývoje lidstva od barbarství k civilizaci. Vymístěné, a tím pádem zespolečenštěné, významy, jsou v tomto mytickém řádu významy zkrocenými. Z perspektivy dekonstrukce je však samotný proces přeměny významů nezkrotitelný. Kultura/civilizace je nevypočitatelná a nezkrotitelná. ${ }^{8}$ Proces vymístění tak není myslitelný jako přeměna významů ve smyslu evoluce a/nebo historie, jež se zakládají na kontinuitě idejí reformulujích se v nových kontextech a přibližujících se tím idejím jasnosti a dokonalosti. ${ }^{9}$

Představa potenciální neregulovatelnosti a nezadržitelnosti přeměny významů, kterou nastiňuje diskurz dekonstrukce, zakrývá mocenské vztahy, které přeměnu významů způsobují, nebo jsou jejím důsledkem. Diskurz psychoanalýzy naopak získává svou významnost právě tím, že propojuje vztahy artikulace významů se vztahy síly (Ricoeur 1974: 263264). Vymístění jako přepsání významů je v diskurzu psychoanalýzy chápané jako akt síly generované mocí společnosti. Reinterpretace je událostí realizace moci. Naopak, diskurz dekonstrukce klade důraz na to, že přeměna významů nemusí být produktem moci cenzury. Přítomnost samopohybu přeměny na poli znaků však sama o sobě nevylučuje možnost přeměny významů, jež je důsledkem intervenující mocenské síly. Představa nepředpověditelné turbulence znaků navíc sama evokuje představu konfliktního pole silových vztahů. Reinterpretace psychoanalytické představy propojenosti přeměny významů a moci nás vede k důrazu na událost vládnutí: k představě moci, jež není permanentní strukturou, ale aktem jednání, intervence. Jako každý význam může získat status původního významu, podobně dochází také k decentralizaci, k diverzifikaci mocenské síly zpơsobující vymístění jako přeměnu významů. Vymístění ve smyslu nikdy nekončící reinterpretace není zakotveno v universální autoritě cenzury, jež je legitimizovaná civilizací. Vykonávání vymístění není privilegiem univerzálně pojatého typu centrálního cenzora. Jinak řečeno: každý se může stát lokálním cenzorem přepisujícím texty. V každém diskurzu se mohou periodicky objevovat 
různé typy institucionalizovaných a samozvaných re-interpretátorů přepisujících dosavadně platné „původní“ významy. Fenomén vymístění ve smyslu přeměny významů nám ukazuje propojenost dynamiky mocenských vztahů s dynamikou diskurzivní produkce symbolických objektů. Nejde pouze o to, abychom na pozadí vztahů označování odhalili silové vztahy moci. Jde o to, upozornit na jejich provázanost.

\section{Vymístění andělů: Přeměna žité prítomnosti symbolických objektů}

Kulturní dynamiku vymístění ve smyslu přepsání, reinterpretace významu symbolických objektů můžeme ilustrovat na př́kladu vymístění nebeských bytostí, konkrétněji andělů. Andělé jsou z naší perspektivy pojímaní jako symbolické objekty konstituované specifickými diskurzy jak systematického bádání, tak praktického rozumu. Přítomnost andělů v životním světě lidských bytostí je projevem srozumitelnosti a smysluplnosti určité formy jazyka, myšlení a jednání. $Z$ hlediska sociologie je tato žitá př́ítomnost symbolických objektů, jejich srozumitelnost a smysluplnost, dílem procesů institucionalizace, kanonizace a kodifikace, které se odehrávají v rámci konfliktního pole interpretací a reinterpretací (Bourdieu 1992). Vymístění jako konceptuální nástroj analýzy ukazuje přeměnu významu symbolických objektů, ke které dochází jednak v podobě přepisu/vrstvení významů (tedy nikoli v podobě nahrazení starého významu novým), jednak v důsledku nikdy nekončící dynamiky centralizujících a odstředivých sil konfliktního pole společnosti a kultury (a tedy nikoli v důsledku působení moci centrální autority).

Př́iběh o vymístění andělů načrtneme nejprve tak, jak ho nacházíme v etablovaném historickém diskurzu (Le Goff a Schmidt 2002, ,angel and demon“ 2003, Davidson 1967, Godwin 1990, Langmuir 1999). Žitá přítomnost nebeských bytostí byla jedním z nejvýznačnějších atributů různých stř̌edověkých světů. Klasický historický př́běh vypráví o proměně této žité prítomnosti. Proces proměny žité př́tomnosti andělů sleduje v rovině jejich měnící se podoby zobrazení a měnící se pozice, které zastávají ve struktuře středověkých světů.

Středověký kult andělů jako legitimní forma uctívání neviditelných bytostí byl významnou součástí církevní strategie inkluze a christianizace polyteistických praktik každodenních forem religiozity. Zásadní roli $\mathrm{v}$ šíření a christianizaci kultu andělů sehrávalo rozšiřování mnišství. Počátky mnišství jako specifické formy života byly spojené s ideálem nejdokonalejšího pozemského ztělesnění andělského života, což se mělo projevit v pohlavní čistotě, kontemplaci, oslavování Boha a ve společném zpívání žalmů. Samotné uctívání andělů bylo objektem institucionální regulace prostřednictvím zavádění svátků, omezení počtu oficiálně uznávaných archandělů a v neposlední řadě kanonizace diskurzivního rádu zobrazení andělů. Vizuální zobrazení andělů sehrálo důležitou roli při vyjádření a interpretaci spirituální zkušenosti, pomohlo představit si původ zla, poslední soud. Diskurzivní rád zobrazení andělů byl kanonizován druhým nikajským koncilem v osmém století, jehož rozhodnutí byla vyhlášením papeže závazná pro celou římsko-katolickou církev, pro křestanskou společnost té doby, a tedy i pro značný podíl nositelů středověkého písemnictví. Andělé v podobě symbolických a ikonických znaků byli př́tomni v nejrůznějších středověkých textech: v teologických a mystických, v textech popisujících vize a životy světců, v textech popisujících kázání či zázraky, v architektonické symbolice či na freskách. Diskurzivní řád regulující zobrazování andělů 
zprostředkovaně ovlivňoval také produkci formalizovaného vědění, které popisovalo a vysvětlovalo povahu andělů a jejich vnitřní diferenciaci.

Vymístění andělů z jejich ,původni““ pozice je v tomto příběhu tematizované skrze proměnu jejich zobrazování a erozi jejich kultu. Změna ve vizuálním zobrazování - patrná v sentimentalizaci, feminizaci a infantilizaci andělů - je výrazem jejich alegorické reinterpretace. $\mathrm{K}$ této proměně zobrazování došlo současně s nástupem kultu světců. Rozšiření kultu světců je vysvětlováno jako reakce na nárůst individuální zbožnosti a na pastorační strategii církve, sledující osobní spásu. S nástupem kultu svatých si andělé zachovávali svou přítomnost především v roli ochránců jednotlivců nebo kolektivit. Nový kult andělů strážných vznikal na úrovni jednotlivců a měst. Rozšíření ideje individualizace posledního soudu, podle kterého je po smrti souzen každý jednotlivec sám za sebe, vedlo ke vzniku kultu osobního andělského průvodce a ochránce. Tento nový kult mohl být navíc spojen i s tehdejším rostoucím vlivem víry v moc d’ábla. Kult andělů ochraňující městské společenství vznikal v katastrofálních podmínkách hrozby moru. Postupně se vytvořil kult strážných andělů některých království. Podobnou funkci ochránců sehrávali také svatí, přičemž nejenom města, ale také každá forma středověkého společenství (od měst až k žebrákům) získávala „vlastního“ svatého ochránce.

Význam andělů je ve výše načrtnutém př́běhu konstituován ve vztahu k duálnímu procesu vymístění. Ukazuje jednak vymístění v podobě procesu přepsání původního významu, jednak vymístění z původní diskurzivní pozice v podobě de-centrace.

Na jedné straně získává v uvedeném př́iběhu kult andělů svůj smysl v podobě legitimní formy uctívání neviditelných bytostí. V tomto smyslu vzniká kult andělů vymístěním lokálních symbolických objektů umožňujících kontakt mezi nebem a zemí. Andělé jsou konstituováni přepisem původních lokálních zprostředkovatelů. V tomto smyslu jsou andělé podobní symbolickým objektům textu snění: vždy odkazují k něčemu jinému, než jsou oni sami. Anděly - včetně andělů padlých - můžeme tedy chápat jako objekty, které úspěšně prošly procesem symbolizace, které se artikulovaly zhuštěním, a na které se přemíst’uje cathexis z jiných objektů ve formě naděje a strachu. Následný proces sekundární korekce pak umístuje tyto symbolické objekty jednak do významotvorného prostředí vyprávění v podobě legend a mýtů, jednak do významotvorného prostředí systematizovaného vědění. ${ }^{10}$ Samotní andělé se dokonce zdají být zvláště vhodní k vymístění původních symbolických objektů. A to tehdy, představíme-li si je jako bytosti, jejichž podstata, základní funkce či původní význam spočívá ve zprostřredkování mezi různými světy.

Načrtnutý př́běh však kromě vymístění lokálních zprostředkovatelů anděly vypráví také o vymístění samotných andělů. Vymístění andělů můžeme uchopit $\mathrm{v}$ průběžném přepisování/ reinterpretaci jak jejich vizuální podoby, tak jejich původního významu. Jejich původní význam přebírají jiné symbolické objekty, přičemž samotní andělé jsou přepisováni novými významy. Již $\mathrm{v}$ př́ípadě mnišství byla andělům připsaná další vrstva významu v podobě zobrazení duchovního ideálu. Paralelní nástup kultu andělů strážných a kultu svatých ukazuje vymístění původního významu andělů a jeho převedení jednak na světce, jednak na anděly reinterpretované, anděly-strážce. Jak zprostř̌edkovávání, tak ztělesnění normativního ideálu jednání se postupně přeneslo $\mathrm{z}$ andělů na světce, nástupem sekularizace pak na slavné národní hrdiny a umělce, např́ílad na básníky. ${ }^{11}$ 
Na druhé straně, kromě toho, že lokální zprostředkovatelé jsou přepsaní do podoby anděla, jsou také vymístěni ze své původní pozice. Lokální zprostředkovatelé jsou souběžně s přepisem jejich statusu zároveň de-centrovaní. V podobě andělů se stávají podřízenými centrální autoritě Boha. Tato de-centrace je uskutečnitelná díky různým vrstvám významu, kterých jsou andělé nositeli v době vymístění lokálních zprostředkovatelů: ,angelos“ bylo původně zcela profánní řecké slovo označující člověka vykonávajícího úkol posla. Andělem se mohl stát každý. Stačilo doručit nějakou zprávu a člověk byl ostatními označen za anděla. Časem, po vykonání tohoto úkolu kurýra, andělem být přestal. V řeckých tragédiích je postava pronášející zprávy o událostech, které nejsou prrímo zdramatizované, ale jejichž znalost je předpokladem pochopení prŕíběhu, označovaná jako anděl (Mendelsohn 2004). K vymístění tohoto původního významu slova „,angelos“ došlo tím, že se slovo „,angelos“ stalo nástrojem překladu hebrejského slova „mal'akh“ původně označujícího nerozlučného společníka Boha, který byl však v době překladu již používán ve významu služebníka a posla Boha (Godwin 1990). ${ }^{12}$ Klasický řecký ,,angelos“ označoval dočasnou rolovou identitu aktéra přenášejícího nějakou zprávu. Naopak hebrejský „,mal’akh“ označoval více než dočasnou a situační rolovou identitu nositele praktiky „angellein“ tj. ohlášení, oznámení. „Mal’akhův“ nerozlučný vztah k Bohu, jeho služebná podřízenost odkazovaly k identitě zakládající se na sociálním vztahu přesahujícím jednotlivé situace. Jinak řečeno, sociální identita andělů byla nerozlučně určována jak funkcionálně tím co dělají (role), tak mocensky jejich vztahem k autoritě (pozice). ${ }^{13}$

Sociologickým př́nosem konceptu vymístění je právě to, že kromě poukazu na historický proces vymístění původních významů poukazuje také na propojenost této průběžné reinterpretace s dynamikou přeuspořádávání sil v sociálních a kulturních polích. Vymístění jako de-centrace umožňuje uchopit právě tuto dynamiku centrifugálních a centripetálních sil. ${ }^{14} \mathrm{Na}$ počátku jsou lokální nebeské bytosti vymístěny do podoby andělů vlivem centralizujícího kultu Boha, a to tím, že jsou vyvlastněny a připoutány k centrální Autoritě. Následné vymístění do podoby andělů strážných odkazuje na lokální vyvlastnění, na de-centrační reinterpretaci církevně institucionalizovaného kultu. Podobně jako institucionální regulace kultu andělů strážných, může být i církevní institucionalizace kultu světců chápána jako krok směrem k centralizujícímu vymístění lokálních kultů.

A podobně jako nás sociologická perspektiva vymístění místo hledání nejpůvodnějšího významů andělů vede $\mathrm{k}$ uchopení permanentního přepisu jejich významů, vede nás též, místo hledání nejdůležitější síly způsobující jejich vymístění, k uchopení permanentního přeuspořádání prostoru sil. Spíše než k identifikaci moci v podobě utlačující autority je prospěšnější vztáhnout vymístění k multiplicitě sil, které tvoří konfliktní pole významů. Z hlediska žité přítomnosti andělů je zásadní působení institucí a diskurzů, které, v podobě symbolického zobrazení podřízenosti nebeských bytostí jedné, centrální autoritě, tj. Bohu, usilují o ustanovení sociální vazby podřízenosti lokálních společností centrální autoritě. Koncept vymístění nám však umožňuje porozumět strategickému působení těchto institucí: lokální a původní významy nemohou být eliminované, mohou však být přepsané, reinterpretované. Teoretický předpoklad, že vymístění se vždy odehrává v poli konfliktních interpretací, nám navíc umožňuje nazírat na tyto instituce směřuící k ustanovení sociální vazby podřizenosti centrální autoritě jako na jednu ze sil působících v tomto poli. Podobně jako jsou staré významy integrované prostřednictvím reinterpretace, neodehrává se úspěšná koncentrace moci v tomto silovém 
poli skrze eliminaci, ale skrze akomodaci, tj. přizpůsobení lokálních institucí a diskurzů. Např́klad středověký kult andělů jako součást strategie inkluze polyteistických praktik souběžně znemožňoval staré a produkoval nové legitimní formy uctívání neviditelných bytostí. Církevní kodifikace diskurzivního rrádu andělů, obdobně jako institucionalizace jejich kultu v podobě uctívání archandělů a andělů strážných, svědčí o strategii kultivace a regulace žité př́tomnosti symbolických objektů prostřednictvím produkce legitimní podoby zobrazení. Pokud se namísto hledání jediné všemocné, centrální síly soustředíme na pole konfliktních sil, bude možné porozumět také samotnému vymístění andělů jako důsledku přeuspořádání pole sil a významů.

\section{Vymístění uvniłř existenciálního prostoru místa pobytu}

Jak můžeme propojit vymístění ve smyslu přepisu významů s vymístěním ve smyslu vyhnání lidských bytostí? Klíčem k tomuto propojení je fenomén „vymístění uvnitř̌“. Jde o situaci, kdy jedinci nejsou vymistěni ze svého místa pobytu ve smyslu vyhnání, nýbrž jsou vymistěni uvnitř svého místa pobytu mocí vnější či vnitřní kolonizace (Bammer 1994). Vymístění uvnitř odkazuje $\mathrm{k}$ situaci, ve které jou určití jedinci vymístěni, přičemž fyzicky zůstávají na místě. Tematizace fenoménu „vymístění uvnitř̌“ nám umožňuje porozumět například traumatickému charakteru post-trianonské mad’arské identity těch, kteří byly vymístěni uvnitř svého místa pobytu do menšinového či podřízeného statusu vlivem reorganizace politického prostoru, a tím pádem i sociálního a kulturního řádu lokálních společností. ${ }^{15}$ Extrémním případem vymístění uvnitř místa pobytu je vymístění těch, kteří byli na základě norimberských zákonů označováni za Židy. Tito jedinci byli vymístěni uvnitř místa svého pobytu ještě před tím, než začali být vymístování z místa svého pobytu, to jest deportováni, ghettoizováni a vyvražd’ováni. ${ }^{16}$ Dalšími př́klady „vymístění uvnitř̌ nám může posloužit poválečná radikální socialistická reorganizace středoevropských společností, jež vedla k vymístění tradičních vyšších a středních vlastnických vrstev.

Fenomén „vymístění uvnitř̛ ukazuje, že zkušenosti odloučení a vyhnání můžeme nejlépe porozumět tehdy, když objasníme vztah lidí k místu jejich pobytu, tj. když porozumíme konstituci vztahu, který je př́tomný a násilně přeměněný v průběhu vymístění. $Z$ tohoto důvodu musíme svou pozornost obrátit $\mathrm{k}$ intersubjektivnímu a symbolickému zprostředkování tohoto vztahu k místu. Zkušenost odloučení a vyhnání můžeme pojednat pouze za přijetí předpokladu, že lidské bytosti se $\mathrm{v}$ průběhu vymístění vztahují k prostoru $\mathrm{v}$ jiném modu zkušenosti, než je zkušenost objektivního pozorovatele geografického prostoru: vztahují se k tomuto prostoru jako k mistu pobytu a nikoliv jako k objektu poznání (Heidegger 1996). V čem však spočívá rozdíl mezi těmito dvěma formami zkušenosti prostoru?

Mohli bychom předpokládat, že odlišnost těchto zkušeností se bude zakládat na emocionalitě či emocionální neutralitě vztahu k místu. Podle této představy se člověk vztahuje k prostoru jako $\mathrm{k}$ místu pobytu tehdy, když zakouší pocit hluboké připoutanosti $\mathrm{k}$ tomuto místu, když se vztahuje $\mathrm{k}$ tomuto místu jako k domovině, $\mathrm{k}$ vlasti. Naopak zkušenost objektivního pozorovatele můžeme charakterizovat emocionální nezúčastněností a odstupem zaručujícím objektivitu poznání. Není to však kritérium emocionální neutrality vztahu, co odlišuje tyto dvě formy zkušenosti. Vždyt', na jedné straně, objektivní pozorovatel může být taktéž hnán silou 
touhy. Touha po pravdě, touha poznávat a odhalit prostor způsobuje, že objektivní pozorovatel může být k danému prostoru připoután též emocionálně. Na straně druhé zase stojí fakt, že lidské bytosti se $\mathrm{v}$ průběhu každodenního pobývání nemusí nutně vztahovat k místu vlastního pobytu emocionálně a reflektivně. Vztah $\mathrm{k}$ místu pobytu se nemusí nutně projevovat $\mathrm{v}$ romantické zkušenosti lásky $\mathrm{k}$ vlasti, může mít zcela profánní podobu zkušenosti dobře známého působiště každodenního běhu existence. Lidé pobývající („místni““) mohou vše kolem zakoušet v modu samožrejmosti. Až rozklad této samozřejmosti, až odloučení od místa pobytu může vést $\mathrm{k}$ emocionálnímu zvýznamňování tohoto vztahu, a to obvykle v podobě nostalgie.

Jakým způsobem můžeme tedy porozumět odlišnosti zkušenosti prostoru jako místu pobytu a zkušenosti prostoru jako objektu poznání? Př́ítomnost lidských bytostí ve světě má jinou povahu než prítomnost věcí, skal či hvězd ve fyzickém prostoru. Lidské bytosti také pobývají v prostoru, ale prostorovost jejich př́tomnosti má existenciální povahu (bytí-ve-světě) a nikoliv pouze ráz fyzického výskytu těles. Elementární formou prostoru není geometrický, prázdný prostor, který by povahu sociálního prostoru získával tím, že se naplní lidskou aktivitou a imaginací. Naopak, místo je reinterpretováno do podoby prázdného fyzického prostoru; svou geometrickou, „čistou“ podobu získává tím, že se vyprázdní: pomocí abstraktní formy imaginace se z něj odmyslí ono „sociálno“. Jedině díky této formě karteziánské imaginace získává prostor podobu objektu, tj. věci, jež je nezávislá na poznávajících subjektech.

Vztah lidských bytostí k prostoru jejich pobytu je určován tím, že tomuto pobytu vždy nějakým způsobem rozumí a na tomto pobytu jaksi lpí. Tato existenciální prostorovost lidských bytostí přitom není míněna ve smyslu nějakého zprostředkujícího elementu mezi „fyzicko-biologickou“ tělesností a „duchovními“" vlastnostmi člověka (Heidegger 1996: 54-57). Nejde o doplněk duchovní podstaty či o nadstavbu materiální tělesnosti člověka. Existenciální prostorovost lidských bytostí odkazuje na skutečnost, že ve světě pobýváme skrze sdílené způsoby starosti, obstarávání a péče. Jinak řečeno, prostor pobytu lidských bytostí je konstituovaný a strukturovaný jejich existencí.

Uspořádání prostoru pobytu lidských bytostí není vysvětlitelné na základě struktury fyzického prostoru jako na existenciálním prostoru nezávislém a určujícím fundamentu. Podobně není jednání a myšlení lidských bytostí obecně vysvětlitelné na základě jejich fyzicko-biologické tělesnosti nebo jejich duchovní podstaty. Uspořádání existenciálního prostoru je dílem určitého způsobu bytí, jenž ztělesňuje komplexitu sdílených forem starosti, obstarávání a péče. Tyto „způsoby starosti“ přitom neodkazují pouze ke kultivujícím modům obstarávání a péče, nýbrž patří mezi ně také zanedbání, zanechání, opuštění či lhostejnost. Komplexita těchto forem je zjevná z toho, že zahrnuje a propojuje jak způsoby obstarávání a péče, které vycházejí z důvěrné obeznámenosti se světem, tak způsoby, které jsou vytvářeny mocí technologické soustavy vědy (Der Bestand). Obstarávání a péče jsou fenomény, které odhalují to, že existence lidských bytostí je nemyslitelná bez lpění na této existenci. Podobně ukazují i to, že lidské bytosti svému bytí ve světě vždy nějak rozumí. Toto rozumění však nemusí být zakotveno v institucionálně osamostatněné a systematizované aktivitě poznávání. Rozumění je vždy již př́ítomné ve chvíli, kdy poznání, věda a technologie přicházejí na scénu.

Jestliže tedy chceme porozumět zkušenosti pobytu, nemůžeme - právě z výše uvedených důvodů - vycházet $\mathrm{z}$ préedstavy člověka jako vědce vyskytujícího se uvnitř fyzického prostoru. Podobně jako se fyzický prostor nachází uvnitř existenciálního prostoru, je poznávání prvkem vzá- 
jemně propletených praktik obstarávání a péče. Jinak řečeno: vymístění uvnitř nebo vyhnání z místa pobytu předpokládají přítomnost lidí v kulturně zvýznamňovaném prostoru, který není zvýznamňovaný čistě za účelem poznávání, nýbrž především jako místo pobytu. Vymístění předpokládá a odhaluje vzájemnou existenciální propojenost lidí a místa. Tato propojenost však vzniká a udržuje se prostřednictvím symbolických forem kultury, které zprostředkovávaji a tím také vytvářejí vztahy mezi místem a pobývajícími, mezi člověkem a jeho vlastní existencí, mezi lidmi navzájem.

Osobitým př́kladem institucionální a diskurzivní produkce vztahu člověka k jeho existenciálnímu prostoru prostřednictvím symbolických objektů jsou vzpomínková místa (Nora 1989). Jsou to místa krystalizace vzpomínek, které jsou objektivizovány v kulturních prostorech katedrál, archivů, muzeí, hřbitovů, paláců, hor, údolí či skal. Tato místa jsou sama o sobě kulturními objekty vzpomínání a spolu se svou existencí vytvářejí kontext vzpomínkových objektů typu pomníků, emblémů a textů. Udržovány každodenními praktikami, zachovávají smysl minulých událostí díky kulturním praktikám společného vzpomínání, rituálů, příběhů a vzdělávacího výkladu expresivního symbolismu, mezi něž patří např́íklad erby, dekorace a motta. Vzpomínková místa oslovují prostřednictvím znovu-zpř́tomnění nějaké události někoho v současnosti. Cestou formování našeho vztahu s lidmi žijícím v minulosti (např́ílad s našimi předky), se formují také naše vztahy s lidmi žijícími v současnosti. Vzpomínková místa vytvářejí sociální prostor současnosti pomocí zprostředkující síly minulosti: konstituují minulost jako symbolický objekt, kolem něhož se vytvář́í kolektivita.

Pierre Nora klade důraz na moderní, prefabrikovaný charakter těchto vzpomínkových míst, které podle něho nahrazují živé formy vzpomínání. Podle jeho názoru je třeba rozlišit historii a vzpomínání. Zatímco vzpomínání se vyznačuje živou přítomností ve společnosti, historie jako moderní institucionalizovaná forma vědění je vždy selektivní a politickou vưlí zatíženou rekonstrukcí minulosti. Nemusíme však sdílet jeho nostalgický diskurz, nemusíme považovat dominaci historie nad vzpomínkovými místy za osudnou. Živé formy vzpomínání, i když vymístěné, přepsané historií, jsou prítomné i v podmínkách modernity. Dokonce i historií prosáknutá vzpomínková místa - jako je památné místo obětí Holocaustu či pohřebišše popravených revolucionářu z roku 1956 - se mohou stát místy živé formy vzpomínání jako jedinečné události. Zkušenost smutku, žalu, hrdosti či nespravedlnosti může být v podmínkách modernity stejně reálná a autentická jako v podmínkách pre-moderní minulosti. Jinak řečeno, nejenom v minulosti, ale i dnes mohou získat vzpomínková místa podobně jako další elementy místa pobytu lidí povahu symbolického objektu (Lefebvre 1991, Certeau 2002). Konkrétní strom či skála se stávají symbolickými objekty v procesu kulturního zprostředkování i v současnosti, a to nejenom tehdy, když získají posvátný charakter v podobě totemu či atributu posvátného místa. Symbolickým objektem se stávají také tehdy, když jsou užívány jako orientační body začleněné do každodenních praktik nebo když jsou jednoduše vplétány do př́běhů. Pojmenovávající a svět-tvořící moc jazyka není totiž výlučně věcí minulosti.

Jazyk není esenciálně a výhradně lidským nástrojem, jehož pomocí vyjadřujeme své myšlenky, popisujeme svět kolem nás a zpřítomňujeme nepř́tomné v aktu vzpomínání či plánování. Pro porozumění dynamice vymístění je třeba myslet jazyk jinak, než jako pouhý systém znaků a kódů zabezpečující koordinaci sociálního jednání. Jazyk není totožný s tím, co je řečeno nebo napsáno. Naslouchání, mlčení, rozumění jsou stejně zásadní součásti jazyka jako jsou vyslovení myšlenky a mluvení. Jazyk je stejně tak prostředím, jako nástrojem (Heidegger 
1996). Lidská kompetence vytvářet věty a porozumět větru či mrkání je příznakem nezbytnosti žít v prostředí jazyka, jež otevírá a udržuje sdílené obzory rozumění.

Prostředí jazyka vytváŕí sdilené životni světy, které umožňují lidem porozumět událostem, vlastnímu životu a zkušenostem jiných (Dreyfus 1990). Jazyk přitom odkazuje k latentním podmínkám porozumění, implicitním a ne-konceptuálním formám vědění. Člověk může myslet partikulárním způsobem (jako např́klad encyklopedista či jezuita) jedině tehdy, když bude schopen porozumět a mluvit jistou formou partikulárního jazyka (jazyka encyklopedistů či jezuitů). A podobně mluvit a rozumět jazyku např́iklad raného křest'anství či sionismu předpokládá obeznámenost s tím, co každý prvotní křest’an či sionista předpokládal jako samozřejmou znalost a významné vědění. Porozumění diskurzivní konstituci symbolických objektů, institucionalizovaným formám vědění a identitě formujících vztahů je cestou k porozumění konstituci životního světa, a tím i vztahu k vlastnímu místu pobytu. Je to právě přítomnost sdílených životních světů, jež vytváří vztah člověka k místu jeho pobytu. ${ }^{17}$

Vztah jedinců k místu pobytu se reprodukuje skrze každodenní udržování jejich životního světa. Vztahy zprostředkované symbolickými objekty jsou zakotveny v žité př́itomnosti a ne $\mathrm{v}$ pouhé objektivní př́tomnosti či ve znalostech dostupných o daném objektu. Prostředkující a kulturní identitu vytvářející moc symbolických objektů je závislá na udržování jejich smysluplnosti prostřednictvím určitého způsobu bytí a jazyka, jenž ztělesňuje komplexitu sdílených forem starosti, obstarávání a péče. Nicméně, neodlučitelně od sdíleného porozumění, jazyk je také prostorem, který umožňuje nedorozumění a vytváření antagonismů. Vymístění je událostí, která se odehrává v prostředí jazyka. Realizuje se přepisem lokálních významů. Vymístění uvnitř prostoru existence je vyvlastněním, reinterpretací lokálních symbolických objektů. ${ }^{18}$ Toto vymístění významů se však může realizovat také zprostředkovaně, prostřednictvím eroze lokálních institucí a diskurzů udržujících žitou přítomnost symbolických objekti̊.

Vymístění významů, vyvlastnění symbolických objektů a rozklad lokálního životního světa jsou ovšem vždy také součástí vymístění z místa pobytu v podobě vyhnání. Vymístění uvnitř místa pobytu bychom však neměli chápat pouze ve smyslu aktu dominance. Jak jsme ukázali na prŕíkladu proměny významů symbolických objektů, andělů, vymístění může být prostředkem lokálních procesů rezistence. Vymístění je také cestou reinterpretace dominantních významů a interpretací.

\section{Závěr}

Vymístění, analyticky uchopené v podobě vrstvení významů, nám umožňuje porozumět situaci, ve které jsou lidské bytosti vymístěny, a přitom zůstávají na místě. Klíčem k propojenosti kulturního a sociálního vymístění je právě tato situace vymístění uvnitř vlastního místa pobytu. Předchozí text vycházel z předpokladu, že k obohacení sociologické imaginace konceptem vymístění může dojít za předpokladu, že budeme reflektovat jednotlivé vrstvy významu samotného konceptu vymístění. Z toho důvodu jsem považoval za důležité načrtnout, jak artikulují význam pojmu vymístění psychoanalýza a dekonstrukce, jak je propojena žitá př́itomnost symbolických objektů s určitou konstelací mocenských vztahů, a v neposlední řadě, jak samotné vymístění předpokládá existenciálně smysluplný vztah k místu pobytu. 
Diskurz psychoanalýzy zobrazuje vymístění ve smyslu procesu převlečení, maskování původního významu snového textu do přijatelné podoby symbolů. Vymístění významů je tedy pojímáno jako dílo cenzury. V tomto bodu je důležité si uvědomit, že tyto cenzurou přepsané významy získávají smysl, koherenci a vnitřní konzistenci ve formě srozumitelného př́běhu. Právě tato intersubjektivní dimenze vyprávění se ukazuje jako zásadní fenomén z hlediska sociologie kultury.

Intersubjektivní rozměr vymístění významů nám ukazuje, že vymístění není propojeno s mocí pouze prostřednictvím škrtající a přepisující autority cenzury, ale také prostřednictvím významových polí přítomných v kultuře. Vymístěné významy musí být vždy smysluplně zasazené do kontextu, který je vytvářen jazykem a věděním. Psychoanalýza tedy představuje východisko k pojetí vymístění jako sociálně dané a kulturně zakotvené přeměny významů. Dekonstrukce na straně druhé, osvobozuje psychoanalytický koncept vymístění od jeho zakotvení v představě původního a skrytého významu. To, že původ a skrytost významu jsou v dekonstrukci chápané situačně, ve smyslu strukturální pozice v určitém poli významů, vede k odhalení, že každý význam se může stát významem původním. Vymístění významů je proto v této perspektivě pojímáno jako proces nikdy nekončící re-interpretace. Nicméně, představa potenciální neregulovatelnosti a nezastavitelnosti vymístění, zastiňuje mocenské předpoklady a důsledky proměny významů. $Z$ toho důvodu považuji za zásadní doplnit tuto perspektivu o představu konfliktních polí společnosti a kultury.

Na prríkladu vymístění nebeských bytostí jsem se snažil poukázat na to, že žitá přítomnost symbolických objektů je následkem určité konstelace mocenských vztahů. Koncept vymístění však umožňuje pojmout mocenské vztahy nikoliv v podobě stabilní struktury, ale dynamického pole sociálních a kulturních konfliktů. Mocenská produkce žité přítomnosti prostřednictvím institucionalizace jednání a kodifikace diskurzů, se tak ukazuje jako součást konfliktního pole interpretací a reinterpretací. Př́iklad vymístění andělů jako procesu vymístění, který se odehrává na poli konfliktních interpretací, ukazuje, že instituce, které směřují k ustanovení sociálních a symbolických vazeb podř́zenosti centrální autoritě, nejsou všemocné, ale jsou jen jednou ze sil působících v tomto poli. Jestliže se namísto hledání pevně zakotvené struktury nebo jediné centrální síly soustředíme na pole konfliktních sil, bude možné porozumět samotnému vymístění významů symbolických objektů jako důsledku přeuspořádání institucí a diskurzů.

Fenomén „vymístění uvnitř‘، místa pobytu ukazuje, že zkušenosti odloučení a vyhnání můžeme nejlépe porozumět tehdy, když objasníme, jak se konstituuje vztah lidí k místu vlastního pobytu. Vymístění předpokládá přítomnost lidí v prostoru, který je kulturně zvýznamňovaný jako místo jejich existence. $Z$ tohoto důvodu je třeba se zaměřit na sociální a intersubjektivní formy zprostředkování tohoto vztahu. Cestou k porozumění konstituci sdíleného životního světa, a tím i vztahu k vlastnímu místu pobytu, je porozumění diskurzivní konstituci symbolických objektů, institucionalizovaným formám vědění a identitě formující sociální vztahy.

\section{Poznámky}

Děkuji Eleonóře Hamar a všem účastníkům projektu Displacement za inspirativní komentáře $\mathrm{k}$ mému rukopisu.

Pro představu vymístění jako vrstvení je třeba opustit představu vertikální/hierarchické struktury označování. Vrstvení je si třeba představit jinak, než v modu jedné vrstvy nad či pod jinou vrstvou. Není nutné, aby se další vrstva textu nacházela nad vrstvou starou. Další vrstva textu může být zaznamenaná vedle vrstvy staré, jako např́iklad v Talmudu. Abychom připsali novou vrstvu, 
nemusíme vše vymazat, stačí to staré přeškrtat. Skrytost vrstvy významu může spočívat v našem nezájmu o tuto vrstvu. Něco může být pro nás skryté, i když je to jinak zjevné. Je to před námi, ale nevšímáme si toho, protože tomu nepřisuzujeme důležitost.

2 Může se ale vynořit otázka: co je pravděpodobnější? Vymístění nebo eliminace? Kterou z těchto možností můžeme považovat za pravidlo? A nejsou př́ípady vymístění spíše výjimkou? Možná, že pojem vymístění reprezentuje jevy, které jsou z pohledu moci menšinové, nepravděpodobné, výjimečné, negenerující zákonitosti. Zaslouží si naši pozornost určitý jev, jestliže jeho důležitost může být zpochybněna ve jménu jeho neobvyklosti? Nemusíme sdílet jazykovou hru, ve které získávají neobvyklé jevy relevanci z důvodu jejich zajímavosti, abychom mohli zdůvodnit význam zkoumání neobvyklých a menšinových jevi̊. V sociologické tradici můžeme najít interpretační rámce, které se odklání od hledání stabilizujících struktur a zákonitostí směrem k hledání prvků nestability a událostí (Lyotard 1984).

3 Nesdílíme přesvědčení o autoritě původu jako o místě podstaty, dokonalosti a pravdy (Foucault 1998), proto náš nástin genealogie konceptu vymístění uznává závažnost, nikoliv však závaznost původního významu.

4 Vymístění/přemístění, kromě vztahu označování, vytváří také vztah hierarchie: jednak mezi původním znakem a jeho náhražkou, jednak mezi původním významem zastupujícího znaku a jeho doplňkem. Díky vymístění/přemístění se z určitého znaku stane sekundární objekt ve smyslu druhořadého a zastupujícího objektu. Nepůvodní, doplňující vrstva významu se naopak stává důležitějším významem.

5 „Ve snovém př́iběhu jsou totiž skryta tajemství vztahující se k celé lidské subjektivitě. [...] všechny př́běhy, které si vyprávíme o sobě samých, jsou sekundárními korekcemi utkanými z přediva nejrůznějších útržků minulého a př́ítomného duševního života: z př́ní a tužeb, fantazie a představ, nadějí a obav" (Mitchell a Black 1999: 41).

6 Intersubjektivita, jako fenomenologický pojem, označuje sdílené vědění a sít' sociálních vztahů vytvářených komunikací.

$7 \quad$ Z hlediska sociologické kritiky je právě tato nahodilost sensitivním bodem. $\mathrm{V}$ př́ípadě, že počítáme s působením moci v procesu vymístění, těžko můžeme sociologicky chápat moc v podobě kontingence. Sociologie je alespoň do určité míry provázána s představou „integrační moci“, která redukuje kontingenci. Je to představa jak normativní, tak produktivní moci, která je neslučitelná s ideou absolutní kontingence.

8 Podivnost a nepřijatelnost těchto metafor je symptomem symbolické moci mýtu civilizace jako prostoru řádu, klidu a krásy.

9 Viz analogickou interpretaci proměny myšlení u Foucaulta (1998).

10 Tento aspekt psychoanalýza netematizuje, nicméně vytvoření systematizovaného vědění je důležitou součástí intersubjektivní podoby interpretace (Schutz a Luckmann 1973, Berger a Luckmann 1967).

11 Diskurz o svatých odkazuje k pozici slávy, kterou individuum získává jednáním, vlastním bojem („saint“ 2003). Vyprávění o tomto jednání vede do „historické“ minulosti, svátost je legitimizována právě jednáním vykonaným v minulosti. Můžeme zde pozorovat analogii s diskurzivním rádem moderního kultu „slavných osobností národa“, ve kterém je prostor nebes vymístěn do času historie.

12 Zprostředkování však není chápáno ani na počátku jako jednostranné. Nejde pouze o zprostředkování vůle Boha lidem, ale také o zprostř̌edkování vůle/proseb lidí Bohu. Tato zprostředkovatelská role je propojena s praktikou modlitby jako formy komunikace mezi zemí a nebem, která předpokládá jinou formu institucionalizace a legitimizace než jakou představují praktiky obětování či meditace. 
13 V dimenzích funkcionální specializace a mocenské hierarchie můžeme sledovat jemnější typizaci a dokonce individualizaci identity andělů. Gabriel (individualizace), který diktoval Korán Mohamedovi, byl archandělem (pozice $v$ hierarchii). Strom života v ráji byl hlídán cherubínem (funkcionálni specializace) se šesti kř́dly.

14 K analogii s koncepty deteritorializace a reteritorializace viz Deleuze a Guattari (1992).

15 Specifickým případem je vymístění těch, kteří sice zůstali v dominantním postavení na vlastním teritoriu, avšak v důsledku post-trianonského ressentimentu zakoušeli vymístění ze svého místa pobytu.

16 Vymístění uvnitř místa pobytu může právě předcházet vymístění z místa pobytu. Holocaust nezačal deportacemi, podobně však nezačal zákony - i když zákony mají v tomto procesu velice významnou roli. Deportace pouze realizovaly, zákony pouze legalizovaly a kodifikovaly situaci „vymístění uvnitř‘“, která byla již v lokálních životních světech institucionalizovaná. Zákony vytvořily nové instituce, ale také legalizovaly instituce a diskurzy již existující. Ještě předtím, než Židy vymístil z místa jejich pobytu právní řád, byli vymístěni sociálním a symbolickým řádem lokálních společností (Goldhagen 1997).

17 I když ve věci propojenosti jazyka, sdíleného světa a situovanosti lidské existence vycházím z Heideggera (1996), považuji za důležité explicitně upozornit na to, že nesdílím romanticko-konzervativní interpretaci historické situovanosti (Geschichtlichkeit). Jinak řečeno, jazyk, svět a spolu-bytí (Mitsein) nemyslím v nacionalistickém, ale ve fenomenologicko-existencialistickém smyslu (o různých formách interpretace díla Bytí a čas viz Wolin 1991, 2001.) Jazyk není Němčinou nebo Mad’arštinou, svět není Němectvím nebo Mad’arstvím, a spolu-bytí nemá podobu Volk neboli Národa. Zmíněné pojmy chápu ve smyslu lokálních symbolických univers lidí pobývajících $\mathrm{v}$ dané lokalitě. Elementární formou lokality z perspektivy této interpretace není rurální prostředí kulturně homogenní vesnice, ale urbánní prostředí kulturně plurálního města. Nepochybuji o vlivu moderních „národních“ kulturních forem na tyto lokální struktury. I když jejich symbolická moc a strategie získání hegemonie spočívá právě ve vyvlastnění, tj. nacionalizaci, lokálních rurálních i urbánních kultur, tyto politicko-kulturní strategie zůstávají jenom jednou ze sil strukturujících lokální sociální prostory.

O ikonoklasmu a kulturní revoluci viz Stites (1996).

\section{Literatura}

Anderson, B. 1998. The Spectre of Comparisons. Nationalism, Southeast Asia and the World. London: Verso.

Anderson, B. 1991. Imagined Communities. London: Verso.

Berger, P. L., Luckmann, T. 1967. The Social Construction of Reality. New York: Anchor.

Bourdieu, P. 1992. Language and Symbolic Power. Cambridge: Polity.

Certeau, M. 2002. The Practice of Everyday Life. Berkeley: University of California Press.

Davidson, G. 1967. A Dictionary of Angels, including the Fallen Angels. New York, Free Press.

Deleuze, G., Guattari, F. 1992. A Thousand Plateaus. London: Continuum.

Derrida, J. 1978a. „Freud and the Scene of Writing.“ In Writing and Difference. London: Routledge, s. 196-231.

Derrida, J. 1978b. „Structure, Sign and Play in the Discourse of the Human Sciences.“ In Writing and Difference. London: Routledge, s. 278-294.

Derrida, J. 1981. Positions. Chicago: University of Chicago Press. 
Dreyfus, H. L. 1990. Being-in-the-World: A Commentary on Heidegger's Being and Time, Division I. Cambridge, Mass.: MIT Press.

Foucault, M. 1970. The Order of Things: An Archaeology of the Human Science. London: Tavistock.

Foucault, M. 1972. The Archaeology of Knowledge. London: Tavistock.

Foucault, M. 1998. „Nietzsche, Genealogy, History.“ In Aesthetics, Method and Epistemology.

London: Penguin, s. 369-392.

Freud, S. 1966. Álomfejtés [Die Traumdeutung]. Budapest: Helikon.

Goldhagen, D. J. 1997. Hitlerovi ochotní katani. Praha: Lidové noviny.

Heidegger, M. 1996. Being and Time. Albany: SUNY Press.

Krupnick, M. (ed.) 1983. Displacement. Derrida and After. Bloomington: Indiana University Press. Langmuir, E. 1999. Angels. London: National Gallery Publications and Yale University Press.

Le Goff, J., Schmidt, J. C. (eds.) 2002. Encyklopedie středověku. Praha: Vyšehrad.

Lefebvre, H. 1991. The Production of Space. Oxford: Blackwell.

Lyotard. J. F. 1984. The Postmodern Condition. Manchester: Manchester University Press.

Mendelsohn, D. 2004. „Winged Messages.“ The New York Review of Books 51: 2.

Nora, P. 1989. „Between Memory and History: Les Lieux de Mémoire.“ Representations, 26: 7-25.

Ricoeur, P. 1974. „The Question of the Subject: The Challenge of Semiology.“ In The Conflict of Interpretations. Evanston: Northwestern University Press, s. 236-268.

Rycroft, C. 1972. A Critical Dictionary of Psychoanalysis. London: Penguin.

Schutz, A., Luckmann, T. 1973. The Structures of the Life-World. Evanston: Northwestern University Press.

Spivak, C. G. 1983. „Displacement and the Discourse of Woman.“ In M. Krupnick (ed.) Displacement. Derrida and After. Bloomington: Indiana University Press.

Stites, R. 1996. „Iconoclastic Currents in the Russian Revolution: Destroying and preserving the Past.“ In A. Gleason (ed.) Bolshevik Culture. Bloomington: Indiana University Press. s. 1-24.

Wolin, R. (ed.) 1991. The Heidegger Controversy. A Critical Reader. New York: Columbia University Press.

Wolin, R. 2001. Heidegger's Children. Hannah Arendt, Karl Löwith, Hans Jonas and Herbert Marcuse. Princeton: Princeton University Press.

,angel and demon" 2003. Encyclopaedia Britannica. From Encyclopædia Britannica Online, HTML dokument dostupný z: http://0-search.eb.com.oscar.edgewood.edu:80/eb/ article? eu $=117210$

„saint” 2003. Encyclopcedia Britannica. From Encyclopædia Britannica Online, HTML dokument dostupný z: http://0-search.eb.com.oscar.edgewood.edu:80/eb/article?eu=117217

\section{Autor}

Csaba Szaló působí na Katedře sociologie Fakulty sociálních studií Masarykovy univerzity v Brně. Zabývá se sociologii kultury. Jeho výzkumné aktivity se zaměřují na proces kulturní asimilace a sociální konstrukce etno-národních identit. Je spolu-editorem knihy Mozaika v re-konstrukci: Formování sociálních identit v současné Střední Evropě. (Brno: MPU 2003). Kontaktní e-mail: szalo@fss.muni.cz 